\title{
Possible Involvement of Keratinocyte Growth Factor and Its Receptor in Enhanced Epithelial-Cell Proliferation and Acquired Recurrence of Middle-Ear Cholesteatoma
}

\author{
Tomomi Yamamoto-Fukuda, Daiyu Aoki, Yoshitaka Hishikawa, \\ Toshimitsu Kobayashi, Haruo Takahashi, and Takehiko Koji
}

Division of Otorhinolaryngology (TY-F, HT), Division of Nephro-Urology (DA), Department of Translational Medical Science, and Division of Histology and Cell Biology, Department of Developmental and Reconstructive Medicine (YH, T. Koji), Nagasaki University Graduate School of Biomedical Sciences, Nagasaki, Department of Otorhinolaryngology (T. Kobayashi), Tohoku University Graduate School of Medicine, Sendai, Japan

\begin{abstract}
SUMMARY: Middle-ear cholesteatoma is characterized by enhanced proliferation of epithelial cells and granular tissue formation. However, the molecular mechanism underlying these pathological changes is largely unknown. Keratinocyte growth factor (KGF) is a mesenchymal cell-derived paracrine growth factor that specifically stimulates epithelial cell proliferation. In the present study, we investigated the possible involvement of KGF and its receptor, KGFR, in the pathogenesis of cholesteatoma using in situ hybridization and immunohistochemistry, respectively. We examined 56 cholesteatoma specimens, and 8 normal skin areas as control. KGF and KGFR expression was examined by immunohistochemistry using rabbit anti-human KGF and anti-human KGFR polyclonal antisera raised in our laboratories against synthetic peptides corresponding to parts of human KGF and KGFR, respectively. KGF protein and mRNA were detected exclusively in stromal fibroblasts and infiltrating T lymphocytes in $80 \%$ of cholesteatoma cases, whereas KGFR protein and mRNA were localized in the epithelium in $72 \%$ of cases. Assessment of the proliferative activity of cholesteatoma using the labeling index for Ki- 67 showed a significantly higher Ki- 67 labeling index $(66 \%)$ in KGF+/KGFR + cases than other cases. There was a significant correlation between KGF $+/ K G F R+$ expression and recurrence. Our results indicate the possible involvement of both KGF and KGFR in enhanced epithelial cell proliferative activity and recurrence of cholesteatoma. (Lab Invest 2003, 83:123-136).
\end{abstract}

$M$ iddle-ear cholesteatoma is a pathologic condition associated with otitis media (Harker, 1977; Tos, 1988), which accompanies hearing loss and occasionally facial palsy (Bagger-Sjoback and Phelps, 1985), and recurrence after surgical treatment is very common (Edelstein and Parisier, 1989). Untreated or advanced cholesteatoma can also lead to serious complications such as skull-bone erosion, brain abscess, and meningitis (Chole, 1992). Unfortunately, however, there is no suitable therapy except surgery, and our understanding of the molecular mechanism underlying the pathogenesis of cholesteatoma is only limited.

\section{DOI: 10.1097/01.LAB.0000050763.64145.CB}

Received October 30, 2002.

This study was supported in part by a Grant-in-Aid for Scientific Research from the Japanese Ministry of Education, Science, Sports, and Culture (no. 1247003 to T. Koji) and by a grant from the Japanese Environment Agency (to T. Koji).

Address reprint requests to: Dr. Takehiko Koji, Department of Histology and Cell Biology, Nagasaki University School of Medicine, 1-12-4 Sakamoto, Nagasaki852-8523, Japan.E-mail: tkoji@net.nagasaki-u.ac.jp
An important pathologic process in middle-ear cholesteatoma is active proliferation of epithelial cells (Kim et al, 2001; Sculerati and Bluestone, 1989; Sudhoff et al, 1995), which is thought to be stimulated by various growth factors, such as epidermal growth factor (Kojima et al, 1994), platelet-derived growth factor (PDGF) (Fujioka and Huang, 1994), transforming growth factor (TGF)- $\alpha$ (Schulz et al, 1993), and TGF- $\beta$ (Lang et al, 1997), as well as pro-inflammatory cytokines, such as interleukin (IL)-1 (Schilling et al, 1992), IL-6 (Bujia et al, 1996), and tumor necrosis factor (TNF)- $\alpha$ (Yan and Huang, 1991). However, even though the expression of these factors has been detected, no significant correlation with proliferation of cholesteatoma epithelial cells has been reported. In addition to the enhanced proliferation of epithelial cells, histopathologic examination of middle-ear cholesteatomas also shows inflamed subepithelial connective tissue and granular tissue formation (Sculerati and Bluestone, 1989; Sudhoff et al, 1995). On the basis of these early findings, we postulated that the enhanced proliferative activity of epithelial cells and inflamed subepithelial stromal cells might be involved in the pathogenesis of middle-ear cholesteatoma. 
Keratinocyte growth factor (KGF), a unique member of the fibroblast growth factor (FGF) family, is a mesenchymal cell-derived paracrine mediator of epithelial cell growth (Finch et al, 1989; Halaban et al, 1991). KGF was originally purified by Rubin et al (1989) from a conditioned medium of human embryonic lung fibroblasts (M426). Later, a high affinity receptor for KGF (KGFR) was cloned by Miki et al (1991) and shown to be an alternatively spliced variant of FGF receptor-2/bek gene (Miki et al, 1992). In normal skin of developing and adult mice, KGF and KGFR mRNA were expressed in the stroma and epithelium, respectively (Finch et al, 1995a; Mason et al, 1994; Werner et al, 1992). Furthermore, enhanced induction of KGF mRNA expression was detected in fibroblasts during wound healing (Staiano-Coico et al, 1993; Werner et al, 1992), and KGFR mRNA was also detected only in epithelial cells of wounded skin (Orr-Urtreger et al, 1993). In addition, the expression of a dominantnegative KGFR transgene in basal keratinocytes led to epithelial atrophy and a substantially delayed reepithelialization of wounded skin (Werner et al, 1994). Previous studies have also indicated that KGFR is activated by binding to KGF, triggering a signal transduction pathway, which in turn stimulates the proliferation of epithelial cells (Alarid et al, 1994; Housley et al, 1994; Koji et al, 1994a). Therefore, it seems quite reasonable to assume that KGF and KGFR play an important role in the pathogenesis of cholesteatoma.

In fact, several studies have recently demonstrated the expression of KGF mRNA by in situ hybridization (Kojima et al, 1996) and KGFR mRNA by reverse transcription polymerase chain reaction (Ishibashi et al, 1997) in cholesteatoma. However, it is also necessary to evaluate the localization of KGF and KGFR proteins immunohistochemically to further pursue the role of KGF and KGFR interaction in a retrospective study of stored, paraffin embedded, pathologic specimens of cholesteatoma. There are no reports, to our knowledge, on the expression of KGF and KGFR proteins in cholesteatoma. Although several antibodies against human KGF are currently available for immunohistochemical analysis of KGF in other tissues (Giri and Ittmann, 2000; Planz et al, 1999), there is a discrepancy in the results between in situ hybridization and immunohistochemistry (Finch et al, 1997; Fukuda et al, 2002; Werner et al, 1992). In normal mouse skin, KGF mRNA was detected in fibroblasts (Finch et al, 1997; Werner et al, 1992), but no immunoreactivity of KGF was detected by immunohistochemistry (Fukuda et al, 2002). Furthermore, concerning KGFR, LaRochelle et al (1995) reported that that protein was detected in skin using a functional KGFimmunoglobulin chimera, but Fukuda et al (2002) reported that no immunoreactivity of KGFR was detected in normal skin by immunohistochemistry. A specific antibody for human KGFR, which can recognize only part of the alternative splicing variant IIIb, is not available yet (Cancilla and Risbridger, 1998). These discrepancies may be caused, at least partly, by the lack of appropriate antibodies that allow local- ization of these molecules in paraffin sections, emphasizing the need to prepare specific antibodies.

In the present study, we first prepared anti-human KGF and anti-human KGFR antibodies by immunizing rabbits against a peptide corresponding to the $\mathrm{N}$-terminal amino acid residues of human KGF and another peptide corresponding to the extracellular third IgG domain amino acid residues of human KGFR. Using these antibodies, we investigated the expression of KGF and KGFR protein in formalin-fixed paraffin-embedded sections of middle-ear cholesteatoma. The distribution of KGF and KGFR mRNA in cholesteatoma were also determined by in situ hybridization. KGF protein and mRNA were detected exclusively in stromal fibroblasts and infiltrating $T$ lymphocytes in cholesteatoma cases, whereas KGFR protein and mRNA were localized in the epithelium. After identification of KGF- and KGFR-expressing cells, we analyzed the correlation between KGF and KGFR expression and proliferative activity of epithelial cells at individual cell level. Those cases positive for both KGF and KGFR were significantly correlated with proliferative activity. Finally, we analyzed the correlation between KGF and KGFR expression and recurrence of cholesteatoma, and there was a significant correlation between combined expression of both KGF and KGFR and recurrence. Our results indicate the possible involvement of both KGF and KGFR in enhanced epithelial cell proliferative activity and recurrence of cholesteatoma.

\section{Results}

\section{Specificity of Anti-KGF and Anti-KGFR Polyclonal Antibodies}

To evaluate the specificity of the prepared anti-KGF and anti-KGFR polyclonal antibodies, we firstly examined the reaction with authentic recombinant human (rh)KGF (19-kDa) and rhKGFR (100-kDa) by Western blotting. As shown in Figure 1a, anti-KGF polyclonal
Fig. 1a

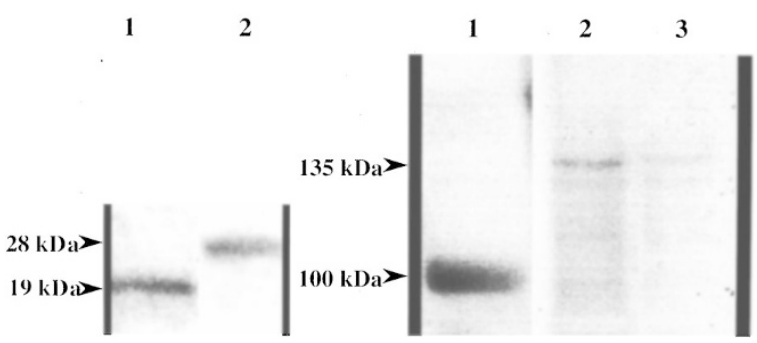

Figure 1.

Western blot analysis of keratinocyte growth factor (KGF) and KGF receptor (KGFR) in rhKGF, rhKGFR, and human middle-ear cholesteatoma. a, rhKGF protein (lane $10.5 \mu \mathrm{g}$ ) and lysate of human middle ear cholesteatoma (lane 2 $25 \mu \mathrm{g}$ ). Lanes 1 and 2, Reacted with $0.5 \mu \mathrm{g} / \mathrm{mL}$ anti-KGF antibody. b, rhKGFR protein (lane $10.25 \mu \mathrm{g}$ ) and lysate of human middle ear cholesteatoma (lanes 2 and $312.5 \mu \mathrm{g}$ ). Lanes 1 and 2, Reacted with $0.05 \mu \mathrm{g} / \mathrm{mL}$ anti-KGFR antibody. Lane 3, reacted with $0.05 \mu \mathrm{g} / \mathrm{mL}$ anti-KGFR antibody preincubated with KGFR (10-1) peptide (500-fold molar excess). 
antibody detected $0.5 \mu \mathrm{g}$ rhKGF with a 19-kDa band (lane 1) and, as shown in Figure 1b, anti-KGFR polyclonal antibody detected $0.25 \mu \mathrm{g}$ rhKGFR with a $100-k D a$ band (lane 1). Next, when the extracts from cholesteatoma tissues were analyzed in a similar fashion, only one 28-kDa band (Rubin et al, 1989) was detected by anti-KGF (Fig. 1a, lane 2), whereas 135kDa (Miki et al, 1992) band expected for KGFR was found with anti-KGFR antibody (Fig, 1b, lane 2). In addition, the latter band decreased from 10-fold to 1-fold when the antibody solution was preincubated with KGFR (10-1) peptide (Fig. 1b, lane 3). These results indicate that these antibodies could specifically detect KGF and KGFR expressed in human cholesteatoma tissue.

\section{Immunohistochemical Localization of KGF and KGFR in Cholesteatoma and Normal Skin Tissues}

In cholesteatoma tissues, intense staining for KGF was detected in stromal cells (Fig. 2A), which were mostly fibroblasts and infiltrating lymphocytes. In addition, a few KGF-positive cells were found in the epithelium. KGFR was predominantly found in the cells of spinous layer and also in some basal and granular cells. The staining was exclusively localized to the plasma membrane (Fig. 2C). Staining for KGF and KGFR was markedly reduced by the addition of the authentic synthetic oligopeptide (8-1 or 10-1) to the first antibody solution (Fig. 2B, 2D), demonstrating the specificity of the immunohistochemical reaction. In addition, when the sections were reacted with preimmune normal rabbit serum instead of the first antibody, no staining was found (data not shown). In three of eight normal skin specimens, KGF was detected in a few stromal fibroblasts (data
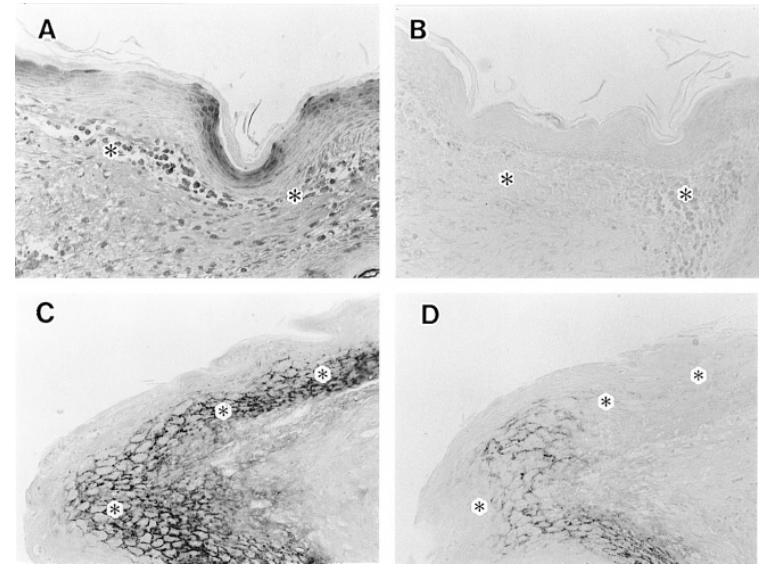

D

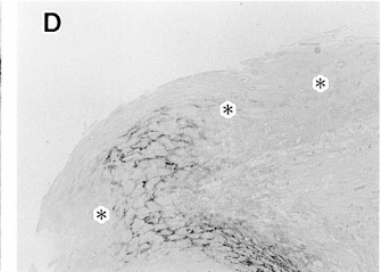

Figure 2.

Immunohistochemical detection of KGF and KGFR in paraffin sections of middle-ear cholesteatoma. A, Immunohistochemistry using anti-KGF antibody. Note the presence of KGF-positive cells in the stroma. B, Competition assay on serial sections by adding excess amount of 8-1 synthetic peptide (500-fold molar excess). C, Immunohistochemistry using anti-KGFR serum. Note the presence of KGFR-positive cells in the epithelium. D, Competition assay on serial sections by adding excess amount of 10-1 synthetic peptide (500-fold molar excess). Asterisks indicate the same lesion in the serial sections. Magnification, $\times 175$. not shown), but in most specimens, KGF was not detected in any stromal fibroblasts (five out of eight specimens) (Fig. 3A). KGFR was scarcely found in epithelial cells except for weak staining within the hair follicles, as reported previously (LaRochelle et al, 1995) (Fig. 3B).
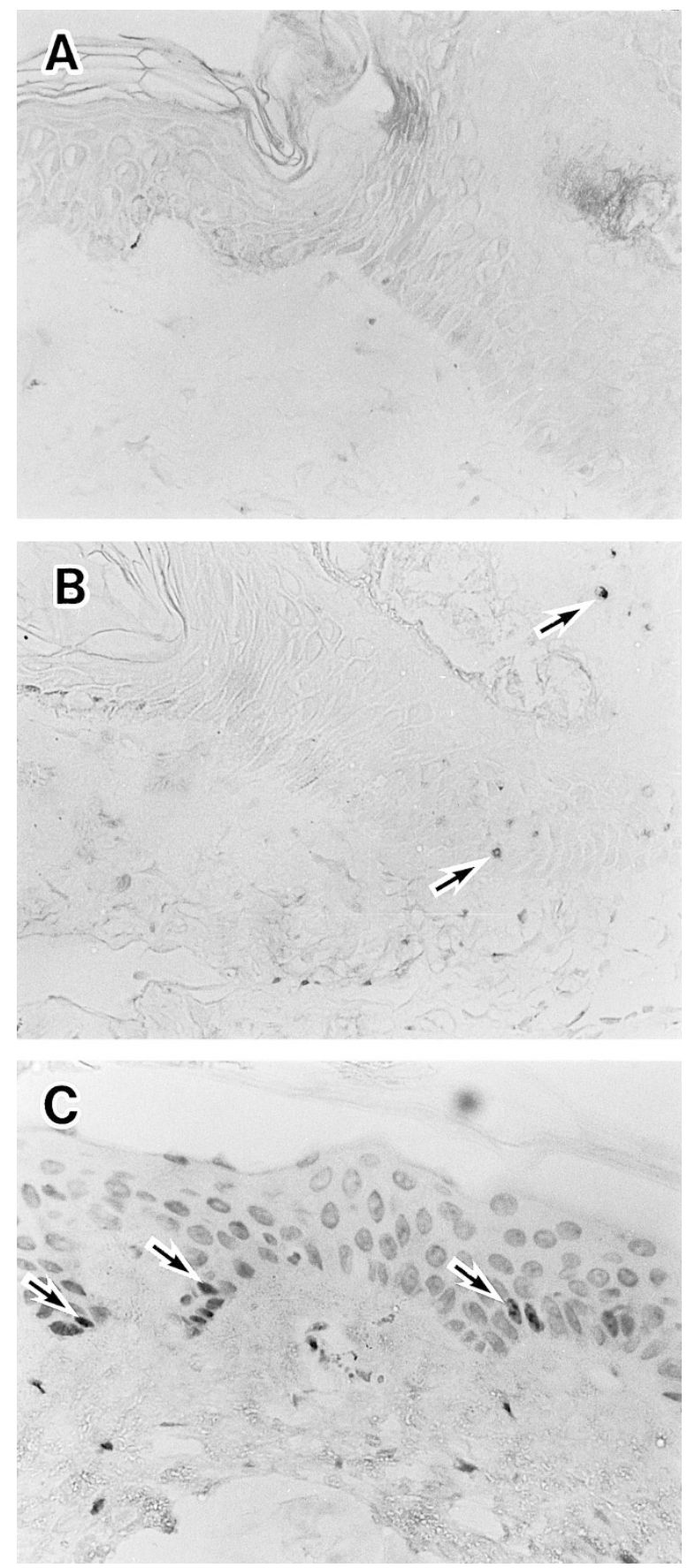

Figure 3.

Immunohistochemical detection of KGF, KGFR, and Ki-67 in paraffinembedded formalin-fixed sections of normal areas of the skin. A, KGF-positive cells are detected in few stromal cells. B, KGFR-positive cells are scarcely found except for weak staining within hair follicles (arrows). C, Ki-67-positive cells are detected in the basal layer. Arrows = positive cells. Magnification, $\times 350$. 
With regard to the proportion of KGF-positive cases, 45 out of $56(80 \%)$ cholesteatomas were positive for KGF whereas that of normal skin was $38 \%$ ( $3 / 8$ specimens). On the other hand, 41 out of 56 (72\%) cholesteatomas were positive for KGFR, but none of the normal skin specimens was scored as KGFRpositive. Cholesteatomas positive for both KGF and KGFR were 37 out of 56 (66\%) specimens.

\section{Localization of KGF and KGFR mRNAs in Cholesteatoma}

To examine the localization of KGF and KGFR mRNAs in cholesteatoma, we performed in situ hybridization. As shown in Figure 4, KGF mRNA was detected in the cytoplasmic area of fibroblasts and lymphocytes in the stroma but not in epithelial cells, which is consistent with the results of immunohistochemistry (Fig. 4, A
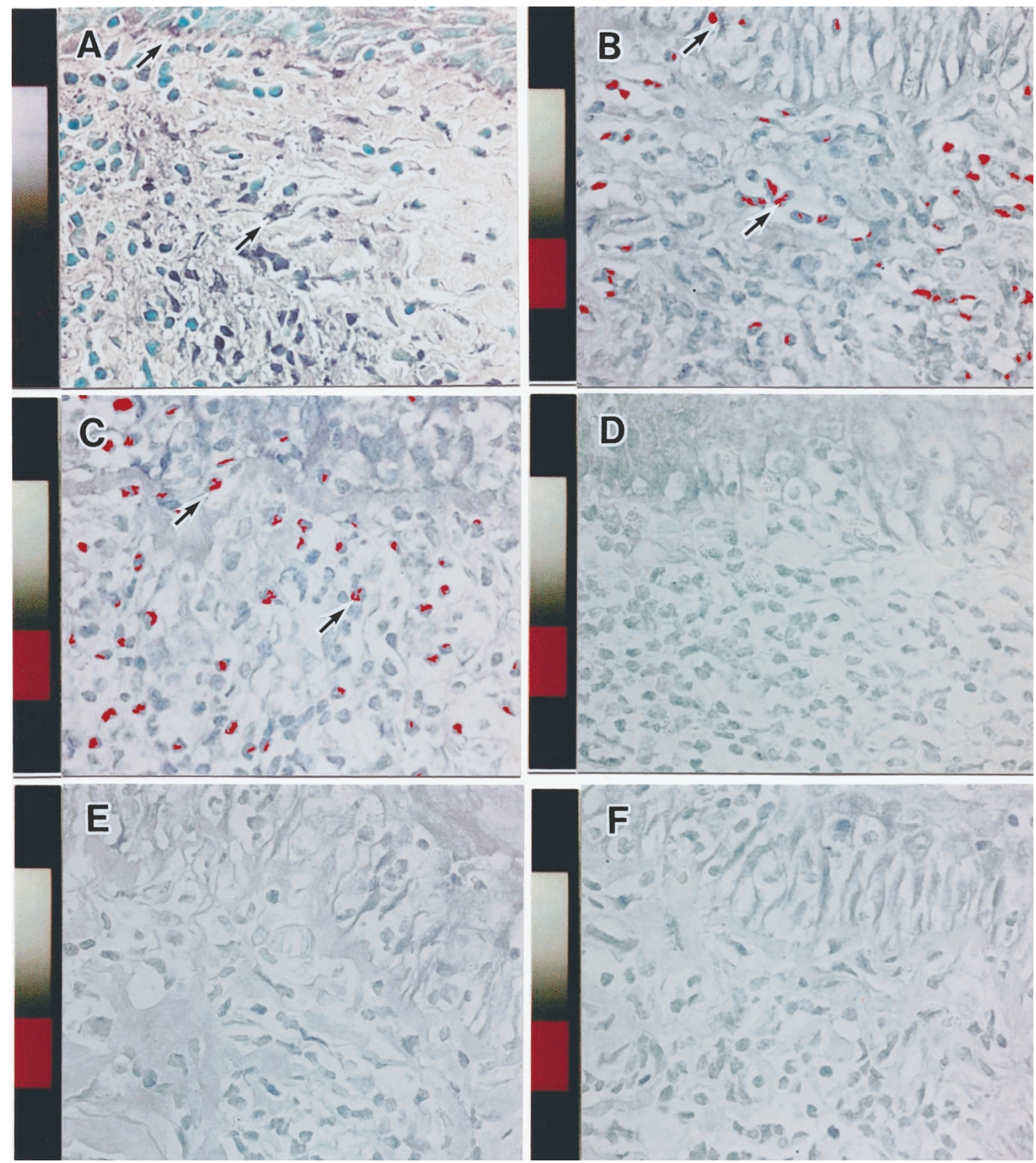

Figure 4.

In situ hybridization of KGF mRNA in adjacent paraffin sections of cholesteatoma. A, Immunohistochemical detection of KGF in a section of cholesteatoma tissue KGF positive cells are stained in black. B, Section hybridized with KGF antisense probe. C, Section hybridized with KGF antisense probe in the presence of an excess amount of random probe. D, Section hybridized with KGF sense probe. E, Section hybridized with KGF antisense probe in the presence of an excess amount of unlabeled sense probe. F, Section hybridized with KGF sense probe in the presence of an excess amount of unlabeled antisense probe. The red color was assigned to positive cells by an image analyzer (B, C, D, E, and F). Arrows = positive cells. Magnification, $\times 350$. 
and B). Interestingly, KGF mRNA-positive lymphocytes were often detected in the epithelium. To confirm the specificity of the mRNA signal, we conducted various control experiments (Fig. 4, C to F). In hybridization with sense probe, no signals were observed (Fig. 4D). Similarly, when an adjacent section was hybridized with thymine-thymine (T-T) dimerized antisense probe in the presence of a 50-fold excess amount of unlabeled antisense or sense KGF oligodeoxynucleotides (oligo)-DNAs, the mRNA signal intensity was markedly decreased (Fig. 4, E and F). On the other hand, when an adjacent section was hybridized with T-T dimerized antisense probe in the presence of a 50-fold excess amount of unlabeled random probe, the signal intensity for KGF mRNA was unchanged (Fig. 4C).

KGFR mRNA was detected in all layers of the epithelium (Fig. 5B), whereas KGFR protein was detected on the surface of basal, spinous, and granular cells (Fig. 5A). To confirm the specificity of the mRNA signals, we conducted various control experiments (Fig. 5C). In hybridization with the sense probe, no signal was observed (Fig. 5C). Similarly, when an adjacent section was hybridized with $\mathrm{T}-\mathrm{T}$ dimerized antisense probe in the presence of a 50-fold excess amount of unlabeled antisense or sense KGFR oligoDNAs, the staining was abolished (data not shown). On the other hand, when an adjacent section was hybridized with T-T dimerized antisense probe in the presence of a 50-fold excess amount of unlabeled random probe, the KGFR mRNA signal was unchanged (data not shown).

\section{Type of KGF-Positive Cells in Cholesteatoma Tissues}

To identify the type of KGF-positive cells, we carried out double-staining for both KGF and various cell surface markers using paraffin sections. As shown in Figure 6, A and B, KGF-positive cells (brown) in the stroma of cholesteatoma were positive for vimentin (blue) but not cytokeratin (blue), indicating that they are likely to be fibroblasts. Moreover, a significant proportion of KGF-positive stromal and epithelial cells (brown) was identified as T lymphocytes because they were positive for CD45R0 (blue) but not for CD20cy (blue) (Fig. 6, C and D). In addition, all S-100-positive cells (blue) in the epithelium were KGF-negative (Fig. $6 \mathrm{E})$.

\section{Correlation between KGF and/or KGFR Expression and Ki-67 Labeling Index}

Immunohistochemical analysis for Ki-67 was performed to compare the proliferative activity of normal skin specimens and cholesteatoma tissues. In the normal skin, Ki-67-positive cells were found only in the basal layer, and the Ki-67 labeling index (LI) was $0.9 \pm$ $0.2 \%$ (Fig. $3 \mathrm{C}$ ). On the other hand, the Ki-67 $\mathrm{LI}$ of cholesteatoma tissues was $9.8 \pm 7.9 \%$, which was significantly higher than that of normal skin specimens ( $p<0.01)$. In cholesteatoma tissues, Ki-67-positive cells were found in the suprabasal and upper layers of
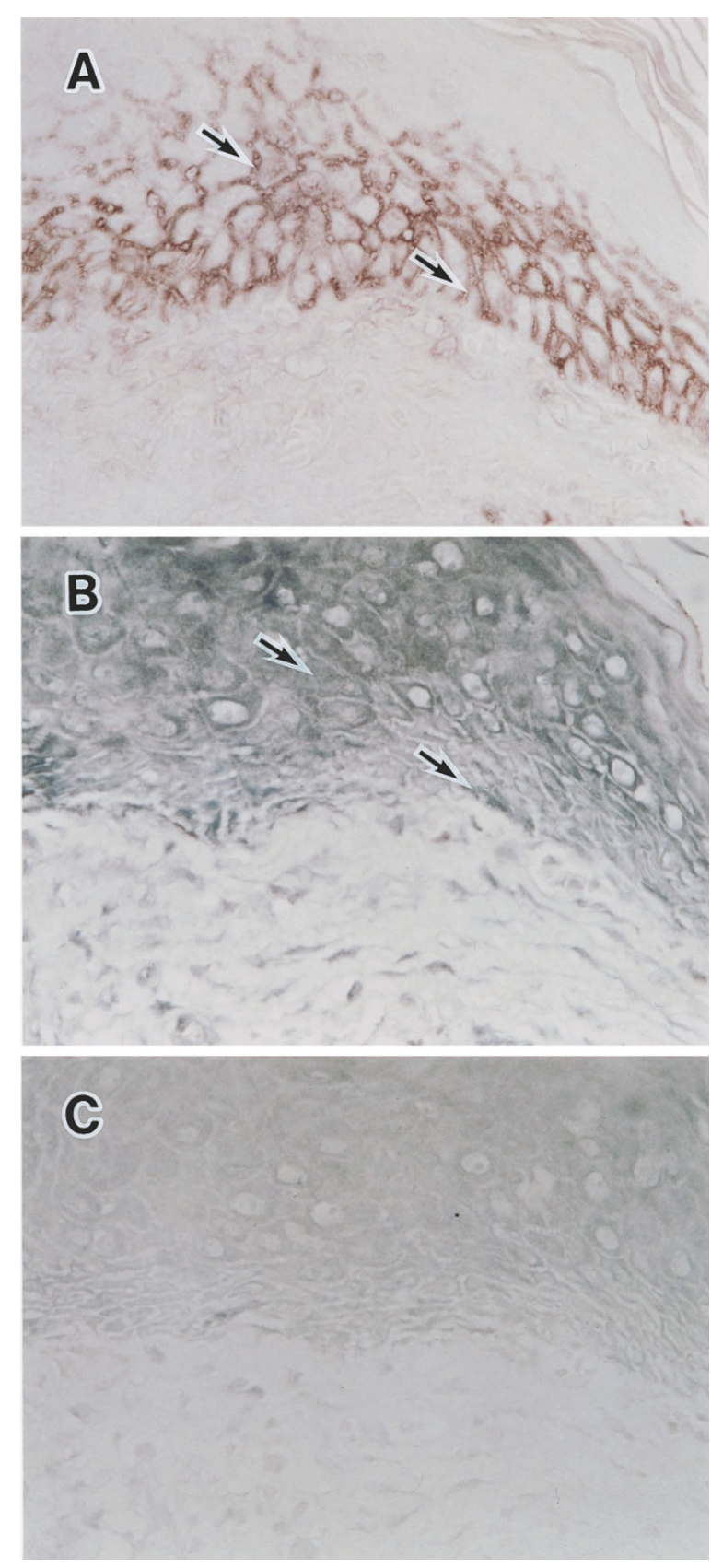

Figure 5.

In situ hybridization of KGFR mRNA in paraffin sections of cholesteatoma. A, Immunohistochemical detection of KGFR in a section of cholesteatoma. B, Section hybridized with KGFR antisense probe. C, Section hybridized with KGFR sense probe. Arrows $=$ positive cells. Magnification, $\times 350$.

the epithelium, which almost corresponded to KGFRpositive layers (Fig. 7).

A higher Ki-67 LI was observed in KGF-positive cholesteatoma tissues than that of negative cases $(11.7 \pm 7.7 \%$ versus $1.9 \pm 2.0 \% ; p<0.01)$. In addition, Ki-67 LI was significantly higher in KGFRpositive cholesteatomas than in negative cases (11.7 $\pm 8.0 \%$ versus $4.5 \pm 5.3 \% ; p<0.01$ ). Moreover, the $\mathrm{Ki}-67 \mathrm{LI}$ of cholesteatomas positive for both KGF and KGFR was significantly higher than that of any other combination $(12.7 \pm 7.7 \%$ versus $4.0 \pm 4.9 \% ; p<$ 

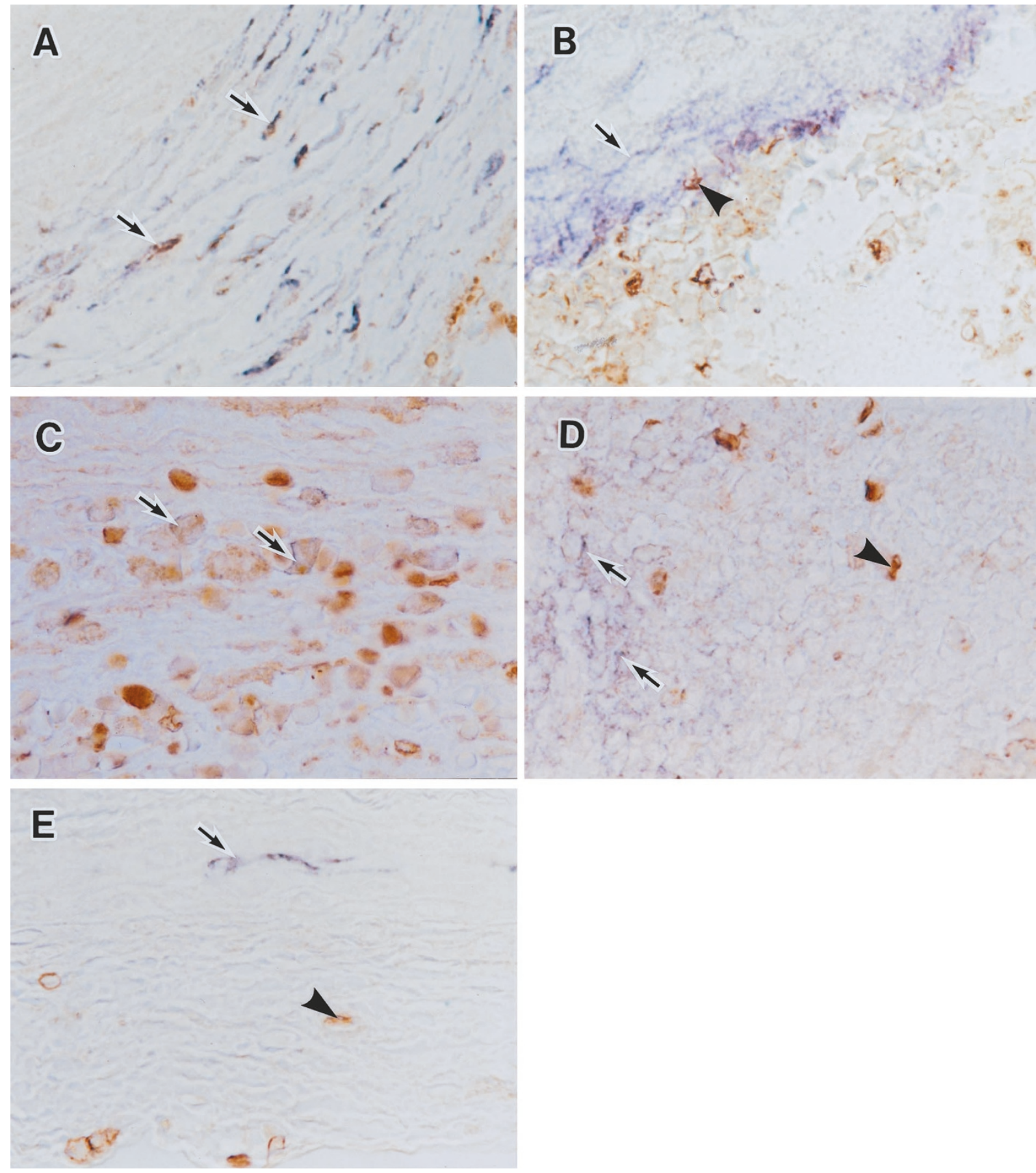

\section{Figure 6.}

Double-staining for KGF and vimentin, pan-cytokeratin (5/6/8/18), CD45R0, CD20cy, and S-100 in paraffin-embedded formalin-fixed sections of middle ear cholesteatoma. A, Double-staining for KGF (brown) and vimentin (blue). Some of the KGF-positive cells are vimentin-positive cells in the stroma (arrows). B, Double-staining for KGF (brown) and pan-cytokeratin (blue). Pan-cytokeratin-positive cells (arrow) are detected in the epithelium, which were KGF-negative cells. KGF-positive cells in the epithelium are pan-cytokeratin-negative cells (arrowhead). C, Double-staining for KGF (brown) and CD45R0 (blue). Some of KGF-positive cells are CD45R0-positive cells (arrows). D, Double-staining for KGF (brown) and CD20cy (blue). Distribution of CD20cy-positive cells (arrow) is different from that of KGF-positive cells (arrowhead). E, Double-staining for KGF (brown) and S-100 (blue). S-100 positive cells are detected in the epithelium (arrow), but their distribution is different from that of KGF-positive cells (arrowhead). Vimentin, pan-cytokeratin (5/6/8/18), CD45RO, CD20cy, and S-100 positive cells were stained in blue, whereas KGF-positive cells are stained in brown. Magnification, $\times 600$.

$0.01)$ such as KGF+/KGFR- (11 cases, $5.6 \pm 5.8 \%)$, KGF-/KGFR+ (4 cases, $2.1 \pm 2.4 \%$ ) or KGF-/ KGFR - cases (4 cases, $1.6 \pm 1.2 \%$ ) (Fig. 8). Interestingly, in all cases that developed recurrence within 18 months after operation, both KGF and KGFR were positive and $\mathrm{Ki}-67 \mathrm{LI}$ was significantly higher than in cases that did not develop recurrence $(20.7 \pm 7.9 \%$ versus $6.8 \pm 5.1 \% ; p<0.01$ ) (Fig. 9). 

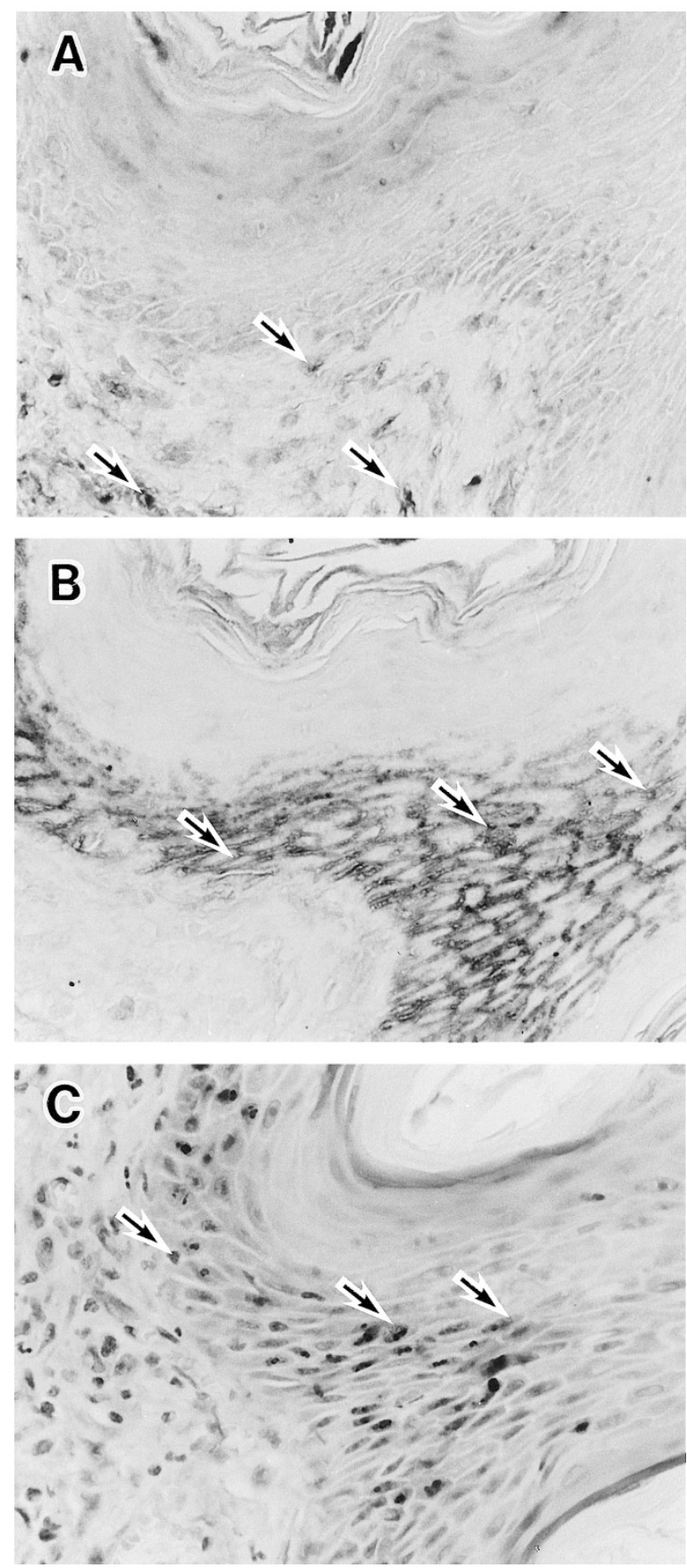

Figure 7.

Immunohistochemical detection of KGF, KGFR, and Ki-67 in serial paraffin sections of middle ear cholesteatoma. A, KGF-positive cells in the stroma. B, KGFR-positive cells in the basal, spinous, and granular layers in the epithelium. C, Ki-67-positive cells in the basal and spinous layers. Arrows = positive cells. Magnification, $\times 350$.

\section{Discussion}

The major findings of the present study were as follows: (a) KGF and KGFR expression in paraffin sections of human cholesteatomas using newly raised antibodies, whose specificity was confirmed by western blotting and in situ hybridization, was detected immunohistochemically (b) KGF expression was predominantly found in stromal fibroblasts and infiltrating

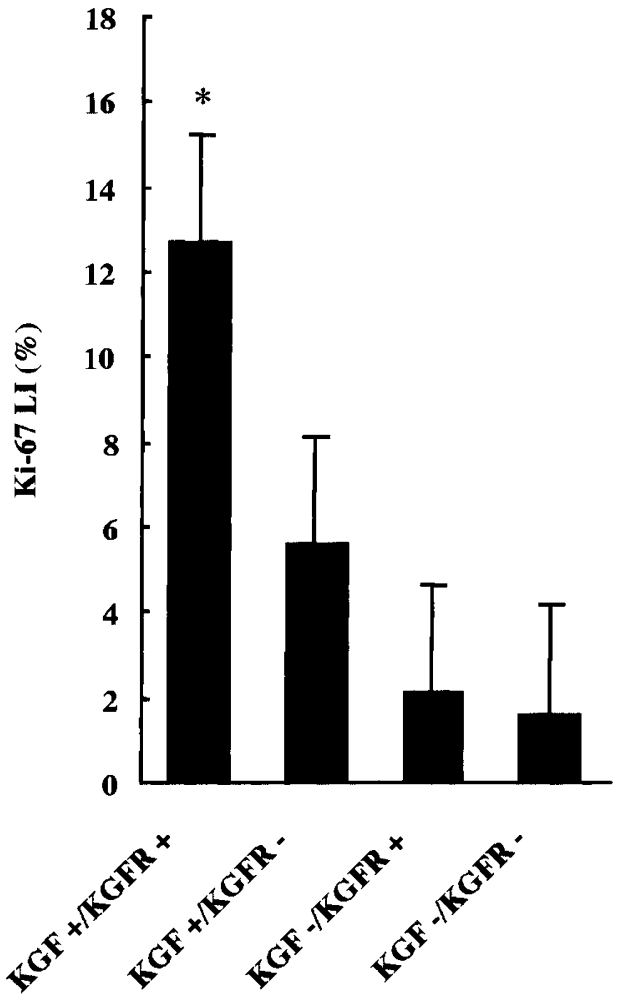

Figure 8.

Correlation between Ki-67 LI and expression of KGF and KGFR in cholesteatoma. Data are mean values of $\mathrm{Ki}-67 \mathrm{LI} \pm \mathrm{SD}$. Bars $=$ double positive cases $(\mathrm{KGF}+/ \mathrm{KGFR}+), \mathrm{KGF}+/ \mathrm{KGFR}-$ cases, KGF-/KGFR + cases, and KGF-/ KGFR - cases. ${ }^{\star} p<0.01$.

T lymphocytes whereas KGFR expression was restricted to epithelial cells, (c) expression of both KGF in the stroma and KGFR in the epithelium significantly correlated with high proliferative activity of epithelial cells, (d) coexpression of both KGF and KGFR in the same cholesteatoma tissue was associated with a high incidence of recurrence, and (e) in normal skin, KGF was expressed in few fibroblasts whereas KGFR was scarcely expressed in epithelial cells.

In cholesteatoma, KGF was mainly localized in stromal cells whereas KGFR was in epithelial cells, indicating their paracrine action. In a variety of tissues including injured lung and wounded skin, KGF regulates the proliferative activity of epithelial cells through a paracrine mechanism (Werner et al, 1992; Yi et al, 1996). In fact, the highest value of Ki-67 LI in epithelial cells was noted in cholesteatoma positive for both KGF and KGFR. More importantly, expression of both KGF and KGFR correlated with recurrence within 18 months after operation. To our knowledge, there is no information on the molecular mechanisms that could affect cell kinetics in cholesteatoma, apart from the study of Choufani et al (1999), who demonstrated major differences between recurrent and nonrecurrent cholesteatomas with respect to the extent of apoptosis, distribution of apoptotic cells, and percentage of calcyclin-positive cells. Taken together, the present results suggest that the interaction between KGF and 


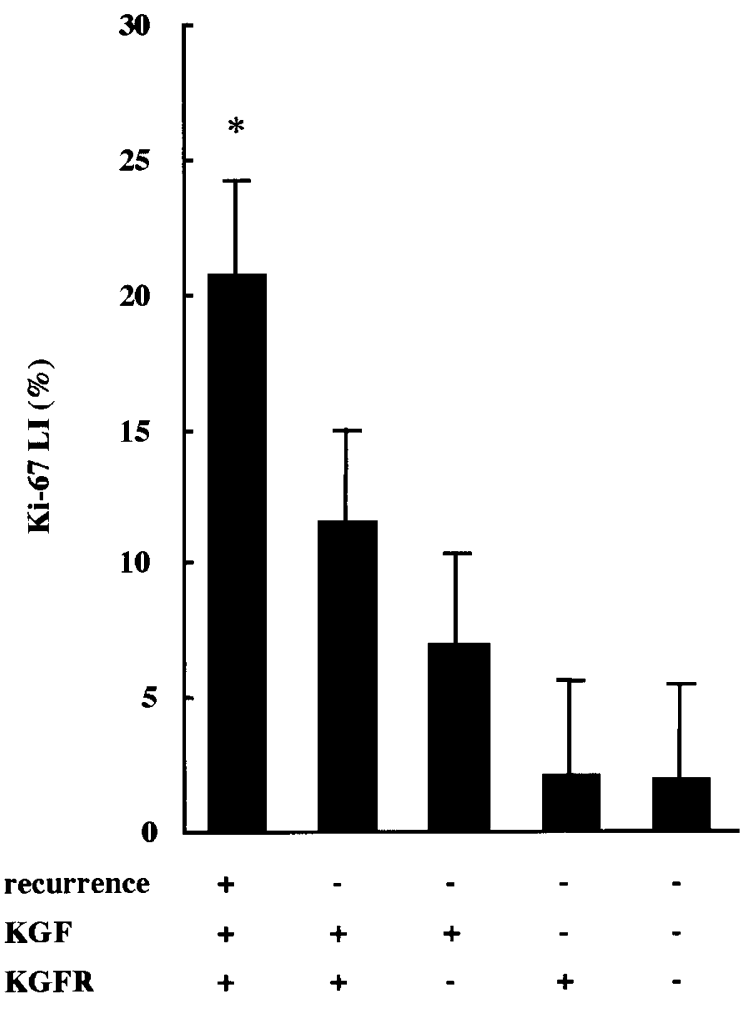

Figure 9.

Correlation between recurrence of cholesteatoma and $\mathrm{Ki}-67 \mathrm{LI}$ and expression of KGF and KGFR. Data are mean Ki-67 LI values $\pm \mathrm{SD}$. Left bar = recurrence cases with $\mathrm{KGF}+/ \mathrm{KGFR}+$ expression. Other bars = cases not showing recurrence with $\mathrm{KGF}+/ \mathrm{KGFR}+, \mathrm{KGF}+/ \mathrm{KGFR}-, \mathrm{KGF}-/ \mathrm{KGFR}+$, and $\mathrm{KGF}-/$ KGFR - expression. ${ }^{\star} p<0.01$.

KGFR may be involved in the recurrence of cholesteatoma.

Our immunohistochemical study revealed the localization of KGFR in the basal, spinous, and granular layers of the epithelium. Analysis of serial sections indicated that Ki-67-positive cells were almost coincident with KGFR-positive cells in the basal layer and lower part of the spinous layer. However, in the granular layer and upper part of the spinous layer, KGFR-positive cells were not positive for Ki-67 antigen. In this context, it should be noted that KGF regulates not only proliferation but also differentiation of human epithelial cells (Andreadis et al, 2001; Marchese et al, 1990; Smola et al, 1993). These results suggest that KGF and KGFR are involved in the control of both proliferation and differentiation of cholesteatoma epithelial cells, resulting in the formation of the hyperplastic epithelium.

Our results also revealed that KGF-positive cells consisted of fibroblasts in the stroma and T lymphocytes in the stroma and epithelium. Kojima et al (1996) indicated that KGF mRNA was expressed only in stromal fibroblasts. However, considering the recent observations that KGF is also expressed in $\gamma \delta$ T cells (Boismenu and Havran, 1994; Finch and Cheng, 1999; Jameson et al, 2002), which are distributed in parts of both epithelial and stromal lesions in many inflammatory dermatoses, (Uyemura et al, 1991) and that $T$ lymphocytes are localized in the stroma and epithelium of cholesteatoma (Schilling et al, 1991; Takasaka et al, 1996), it is not surprising that $\mathrm{T}$ lymphocytes infiltrating the stroma and epithelial cells produce KGF. Actually, in our experiments, KGF mRNA was detected in not only fibroblasts but also $T$ lymphocytes in cholesteatoma.

$\mathrm{T}$ lymphocytes are generally thought to produce several cytokines, which enhance the proliferation of epithelial cells in cholesteatoma (Takasaka et al, 1996). However, previous studies indicated that $\gamma \delta T$ cells down-regulate the frequency of cell death in murine small bowel (Brunner et al, 2001). Moreover, KGF down-regulates cell death of alveolar epithelial type II cells (Barazzone et al, 1999; Fehrenbach et al, 2000). In our study, there was no difference in the number of epithelial apoptotic cells in cholesteatoma and normal skin (data not shown). Therefore, infiltrating T lymphocytes that produce KGF may enhance the proliferative activity of epithelial cells in cholesteatoma rather than the inhibition of epithelial cell death.

Previous studies have documented the infiltration of inflammatory cells in cholesteatoma and overexpression of pro-inflammatory cytokines such as PDGF, TGF- $\alpha$, IL-1, and TNF- $\alpha$ (Bujia et al, 1996; Fujioka et al, 1994; Lang et al, 1997; Schulz et al, 1993). On the other hand, certain growth factors such as PDGF as well as pro-inflammatory cytokines, including IL-1 and TNF- $\alpha$, can stimulate the expression of KGF (Brauchle et al, 1994; Chedid et al, 1994; Finch et al, 1995b). These findings suggest that these cytokines might be responsible for the increased expression of KGF in cholesteatoma. In fact, we can detect a correlation between the degree of inflammation and the levels of KGF expression (data not shown). Furthermore, recent studies reported invading squamous epithelia with altered growth properties in cholesteatoma (Kim et al, 2002). On the basis of these findings, it is possible that KGF and KGFR expression induced by proinflammatory cytokines might be involved in the enhanced epithelial cell proliferation, which is a major pathogenic process in cholesteatoma. Indeed, overexpression of KGF has been detected in other human inflammatory diseases such as psoriasis (Finch et al, 1997) and inflammatory bowel diseases (Bajaj-Elliott et al, 1997; Brauchle et al, 1996), suggesting the important role of KGF in the pathogenesis of inflammatory diseases.

In conclusion, our newly raised antibodies against KGF and KGFR were very useful for localization of KGF and KGFR protein in paraffin sections of cholesteatomas, confirming the differential distribution of KGF and KGFR; the former was expressed in stromal cells whereas the latter was expressed in epithelial cells. Furthermore, we found that cholesteatoma expressing both KGF and KGFR had high Ki-67 LI, which correlated with recurrence. These results strongly indicate that the paracrine action between KGF and KGFR may play an important role in the pathogenesis of cholesteatoma. 


\section{Materials and Methods}

\section{Biochemicals and Chemicals}

rhKGF consisting of 163 amino acid residues was purchased from Pepro Tech EC (London, United Kingdom). The molecular mass of rhKGF was $19-\mathrm{kDa}$ as confirmed in SDS-PAGE. rhFGF R $\alpha 2$ (IIlb)/Fc chimera protein (rhKGFR) was purchased from R\&D Systems (Minneapolis, Minnesota). The chimeric protein was expressed in Sf 21 cells using a baculovirus expression system, and its molecular mass was $100 \mathrm{kd}$ in SDS-PAGE. 2-mercaptoethanol and paraformaldehyde were purchased from Merck (Darmstadt, Germany), and 3, 3'-diaminobenzidine-4HCl (DAB) EDTA was purchased from Dojin Laboratories (Kumamoto, Japan). Trypsin 250 was purchased from ICN (Aurora, Ohio). The electrogenerated chemiluminescence system was purchased from Amersham Pharmacia Biotech UK (Buckinghamshire, United Kingdom). The protein assay kit and a mixed bed resin (AG501-X8(D) Resin 20 50 mesh) were purchased from Bio-Rad Laboratories (Tokyo, Japan). 3-aminopropyltriethoxysilane, proteinase K, BSA (minimum 98\%), yeast transfer RNA, salmon testis DNA, dextran sulfate, polyvinylpyrrolidone, Brij 35, Tween 20, and Triton X-100 were purchased from Sigma Chemical (St. Louis, Missouri). Formamide was purchased from Nacalai Tesque (Kyoto, Japan). Ficoll 400 was purchased from Pharmacia (Peapack, New Jersey). All other reagents used in this study were purchased from Wako Pure Chemicals (Osaka, Japan) and were of analytical grade.

\section{Preparation of Polyclonal Antibodies against KGF and KGFR}

Polyclonal antibodies against KGF and KGFR were prepared by immunization of rabbits against synthetic peptides in cooperation with Nichirei Co. (Tokyo, Japan). To generate anti-KGF antibody, we selected a synthetic oligopeptide sequence 8-1 (SPERHTRSYDYMEGGDI) corresponding to the $\mathrm{N}$-terminal amino acid residues (No. 48-64) of human KGF (Finch et al, 1989). To generate an anti-KGFR antibody, we selected a synthetic oligopeptide sequence, 10-1 (CKVSNYIGQANQ), corresponding to the part of alternative splicing variant IIlb (No. 340-351), which is located in the extracellular third IgG domain amino acid residues of human KGFR (Miki et al, 1992) and is different from FGFR2c (Johnson et al, 1991). Briefly, the antisera against human KGF and KGFR synthetic oligopeptides were prepared, as described previously (Koji et al, 1994b). Antisera were obtained from rabbits immunized with these peptides conjugated with keyhole limpet hemocyanin through the C-terminal cysteine. Titration of antisera was performed by an enzyme-linked immunosorbent assay with the peptides used for immunization as antigens. The sera were prepared when the antibody titers reached plateau levels. Some aliquots of sera were further fractionated to IgG. IgG was purified from the antiserum first by precipitating immunoglobulins with ammonium sulfate, then by using protein $A$ agarose column. An aliquot of anti-KGF and anti-KGFR IgG was affinitypurified using oligopeptide sequence $8-1$ or 10-1, respectively. These antisera resulted in a specific and reproducible immunostaining of paraffin embedded sections of human tissues. For Western blot analysis of KGF and KGFR, $0.05 \mu \mathrm{g} / \mathrm{ml}$ affinity-purified antiKGF antibody and $0.5 \mu \mathrm{g} / \mathrm{ml}$ affinity-purified antiKGFR antibody were used as the first antibody. On the other hand, for immunohistochemical analysis in paraffin sections, $0.5 \mu \mathrm{g} / \mathrm{ml}$ affinity-purified anti-KGF antibody and anti-KGFR antisera $(1: 8000)$ were used to identify KGF or KGFR expression, which yielded the highest signal/noise ratio in immunostained paraffinembedded sections of human cholesteatoma tissues.

\section{Other Antibodies}

Other antibodies used in the present study are listed in Table 1. A mouse monoclonal antibody against Ki-67 (1:100) was purchased from Immunotech (Marseille, France). A mouse monoclonal antibody against human vimentin (1:100), which was used to identify endothelial cells, fibroblasts, smooth muscle cells, and lymphocytes (Osborn et al, 1984), and a mouse monoclonal antibody against human cytokeratins $5,6,8$, and 18 (pan-cytokeratin [5/6/8/18]) (1:200), which was used to identify all epithelial cells (Gatter et al, 1982; Moll et al, 1982), were purchased from Novocastra Laboratories (Newcastle, United Kingdom). A mouse monoclonal antibody against CD45R0, which was used to identify activated T lymphocytes (Norton et al,

Table 1. List of Primary Antibodies for Immunohistochemistry

\begin{tabular}{llc}
\hline \multicolumn{1}{c}{ Antigen } & \multicolumn{1}{c}{ Antibody } & Working dilution \\
\hline KGF & Polyclonal; Human KGF & $0.5 \mu \mathrm{g} / \mathrm{ml}$ \\
KGFR & Polyclonal; Human KGFR & $1: 8000$ \\
Ki-67 & MIB-1 & $1: 100$ \\
Vimentin & NCL-VIM-V9 & $1: 100$ \\
Cytokeratin 5, 6, 8 and 18 & NCL-PAN-CK & $1: 200$ \\
CD45R0 & UCHL-1 & $1: 50(5.4 \mu \mathrm{g} / \mathrm{ml})$ \\
CD20cy & L26 & $1: 100(3.55 \mu \mathrm{g} / \mathrm{ml})$ \\
S-100 & Polyclonal; Cow S-100 & $1: 400(0.275 \mu \mathrm{g} / \mathrm{ml})$ \\
\hline
\end{tabular}

KGF = keratinocyte growth factor; KGFR = KGF receptor; MIB is a registered trademark of Monotes GmbH; NCL-VIM-V9 = Novo Castra Laboratories-VimentinClone V9; NCL-PAN-CK = Novo Castra Laboratories-pan-cytokeratin. 
1986; Smith et al, 1986; Terry et al, 1988), mouse monoclonal antibody against CD20cy, which was used to identify B lymphocytes (Cartun et al, 1987; Mason et al, 1990), and rabbit polyclonal antibody against S-100, which was used to identify Langerhans cells in the skin (Cocchia et al, 1981; Nakajima et al, 1982), were purchased from Dako (Glostrup, Denmark). Horseradish peroxidase (HRP)-conjugated donkey anti-rabbit IgG $(1: 10,000)$ was purchased from Amersham. HRP-goat anti-mouse IgG F(ab)' (1: 100) was purchased from Chemicon International (Temecula, California) and HRP-goat anti-rabbit IgG $F(a b)^{\prime}(1: 100)$ was purchased from Medical \& Biological Laboratories (Nagoya, Japan). HRP-mouse antiT-T antibody (1:80) was purchased from Kyowa Medex (Shizuoka, Japan). Normal goat lgG, normal rabbit IgG, normal mouse lgG, and normal rabbit serum were purchased from Sigma.

\section{Cholesteatoma Specimens and Recurrence}

Cholesteatoma specimens were obtained during surgery on 56 patients at the Department of Otolaryngology, Nagasaki University School of Medicine (from February 1996-May 2000) (Table 2). All patients gave informed consent to surgery and the present study. Thirty-two patients were men and 24 patients were women. The average age was 35 years. With regard to prognosis, 5 of 56 patients developed recurrence of cholesteatoma within 18 months after the initial surgery.

\section{Tissue Preparation}

Five of 56 specimens were used for Western blot analysis, and all 56 specimens were used for immunohistochemistry. As a control, normal skin areas were collected from the cartilaginous portion of the external ear canal or from the retroauricular region of 8 cholesteatoma patients. After excision, 5 of these specimens were frozen immediately on dry ice and later used for Western blot analysis. Each of 56 specimens was fixed in $10 \%$ buffered formalin at room temperature (RT) overnight and embedded in paraffin. Serial sections were cut to $4 \mu \mathrm{m}$ thickness and then placed onto 3-aminopropyltriethoxysilane-coated glass slides, and adjacent sections were stained with hematoxylin and eosin and processed for immunohistochemical analysis of KGF, KGFR, Ki-67, and cell markers.

\section{Western Blot Analysis of KGF and KGFR}

Middle-ear cholesteatoma specimens (100-160 mg for each specimen) were homogenized with a Polytron tissue disrupter (Kinematica, Basel, Switzerland) in lysis buffer (Koji et al, 1994a; Wilson et al, 1999) (20 mм Tris- $\mathrm{HCl}, \mathrm{pH} 7.4,1.0 \mathrm{M} \mathrm{NaCl}, 5 \mathrm{~mm}$ EDTA, $1 \mathrm{~mm}$ phenylmethylsulfonylfluoride, $10 \mu \mathrm{g} / \mathrm{ml}$ aprotinin, 10 $\mu \mathrm{g} / \mathrm{ml}$ leupeptin, $10 \%$ glycerol, and $0.5 \%$ Triton $\mathrm{X}-100$ ) on ice. After centrifugation at $15,000 \mathrm{rpm}$ for 30 minutes at $4^{\circ} \mathrm{C}$, the supernatants were collected and stored at $-80^{\circ} \mathrm{C}$. The protein concentration of each preparation was determined using a kit from Bio-Rad Laboratories according to the instruction provided by the manufacturer, using BSA as a standard. As a positive control, rhKGF and rhKGFR were also processed. In the next step, 12.5, 25, and $50 \mu \mathrm{g}$ of sample lysates and the recombinant proteins were mixed with the loading buffer (2.5\% SDS, $200 \mathrm{~mm}$ Tris- $\mathrm{HCl}, \mathrm{pH}$ 8.0, $0.5 \mathrm{M}$ sucrose, $5 \mathrm{~mm}$ EDTA, 0.01\% bromophenol blue, and $429 \mathrm{~mm}$ 2-mercaptoethanol), boiled for 5 minutes, and loaded on each lane. Samples were separated by SDS-PAGE with a 4 to $20 \%$ gradient gel (Daiichi Pure Chemicals, Tokyo, Japan) or 10-20\% gradient gel (Daiichi) according to the method of Laemmli (1970) and electrophoretically transferred to a polyvinylidene difluoride membrane (Immobilon, Millipore Corporation, Bedford, Massachusetts). The membranes were blocked with PBS containing 5\% nonfat dry milk and 5\% BSA overnight at $4^{\circ} \mathrm{C}$ and then incubated for 2 hours with the first antibody $(0.5 \mu \mathrm{g} / \mathrm{ml}$ anti-KGF antibody or $0.05 \mu \mathrm{g} / \mathrm{ml}$ anti-KGFR antibody) with the blocking solution. After washing, the membranes were reacted with HRPconjugated donkey anti-rabbit IgG at a 1:10,000 dilution as the second antibody for 35 minutes at RT. Finally, signals were visualized by the electrogenerated chemiluminescence system. To confirm the specificity of the reaction, 1,000-fold excess of synthetic peptide KGF (8-1) or KGFR (10-1) was used in the competition assay.

\section{Immunohistochemistry for KGF and KGFR}

Enzyme immunohistochemistry was performed to examine the expression of KGF and KGFR in tissue sections. For this purpose, cholesteatoma paraffin sections were deparaffinized with toluene and rehydrated by serially graded ethanol solutions. For KGFR detection, the slides were pretreated with $0.2 \%$

Table 2. Cases with Recurrent Cholesteatoma

\begin{tabular}{|c|c|c|c|c|c|c|}
\hline & $\begin{array}{c}\text { Number } \\
\text { (male/female) }\end{array}$ & $\begin{array}{l}\text { Age } \\
\text { (yr) }\end{array}$ & Ki-67 LI & $\begin{array}{c}\text { KGF positive } \\
\text { cases (\%) }\end{array}$ & $\begin{array}{c}\text { KGFR } \\
\text { positive } \\
\text { cases (\%) }\end{array}$ & $\begin{array}{c}\text { KGF/KGFR } \\
\text { positive } \\
\text { cases }(\%)\end{array}$ \\
\hline Recurrence (-) & $51(28 / 23)$ & 37 & $8.6 \pm 7.2$ & $40(78)$ & $36(71)$ & $32(63)$ \\
\hline Recurrence $(+)$ & $5(4 / 1)$ & 12 & $20.7 \pm 7.9^{a}$ & 5 (100) & 5 (100) & 5 (100) \\
\hline Total & $56(32 / 24)$ & 35 & $9.8 \pm 7.9$ & $45(80)$ & $41(72)$ & $37(66)$ \\
\hline
\end{tabular}

$\mathrm{KGF}=$ keratinocyte growth factor; KGFR $=$ KGF receptor.

${ }^{a} p<0.01$. 
TritonX-100 in PBS for 15 minutes at RT. After inactivation of endogenous peroxidase activity with $0.3 \%$ $\mathrm{H}_{2} \mathrm{O}_{2}$ in methanol (RT, 30 minutes), the sections were preincubated with $500 \mu \mathrm{g} / \mathrm{ml}$ normal goat IgG and 1\% BSA in PBS for 1 hour to block nonspecific reaction with the first antibody. Then, the sections were incubated with the first antibody at $0.5 \mu \mathrm{g} / \mathrm{ml}$ anti-KGF antibody and 8000-fold dilution for anti-KGFR antisera overnight, washed three times with $0.075 \%$ Brij 35 in PBS, and reacted with HRP-goat anti-rabbit IgG (1:100) for 1 hour. After the slides were washed with $0.075 \%$ Brij 35 in PBS, HRP sites were visualized with $\mathrm{DAB}, \mathrm{Ni}, \mathrm{Co}$, and $\mathrm{H}_{2} \mathrm{O}_{2}$ according to the method of Adams (1981). For negative control, normal rabbit IgG or normal rabbit serum was used instead of the first antibodies, respectively, in every experiment. Some sections were also incubated with the first antibody in the presence of an excess amount of synthetic oligopeptide (500- or 1000-fold molar excess), which was used to raise the antibody.

\section{Probes and Labeling}

Sense and antisense oligo-DNA sequences corresponding to nucleotides No. 648-683 of the human KGF cDNA sequence (Finch et al, 1989) and nucleotides No. 1388-1432 of the human KGFR cDNA (Miki et al, 1992) were synthesized on a DNA synthesizer (Applied Biosystems, Foster City, California). These 36- and 45-base oligo-DNAs were added with two repeats of adenine-T-T at 5 ' and 3 ' ends, respectively, for T-T dimers (Koji and Nakane, 1996). We conducted a computer-assisted search (GenBank nucleic acid sequence database Release 129) of the above KGF and KGFR oligo-DNA sequences (without ATT repeats) and found $100 \%$ homology with those mRNA sequences. These KGF and KGFR oligo-DNAs were haptenized by introducing T-T dimers by $12,000 \mathrm{~J} \mathrm{~m}^{-2}$ UV irradiation, as described previously (Koji and Nakane, 1996). We performed immunodetection and dot-blot hybridization by using KGF and KGFR probes described previously in detail (Koji and Nakane, 1996; Yoshii et al, 1995), and these results indicated that antisense probes were specific and had adequate sensitivity to be useful for in situ hybridization. We also chose a random probe, which had no homology with any specific probes.

\section{In Situ Hybridization}

In situ hybridization was performed as described previously (Koji et al, 1994a). Briefly, cholesteatoma paraffin sections were deparaffinized with toluene and rehydrated by serially graded ethanol solutions. The slides were treated with $0.2 \mathrm{~N} \mathrm{HCl}$ for 20 minutes, $0.2 \%$ Triton $\mathrm{X}-100$ in PBS for 10 minutes, and proteinase $\mathrm{K}\left(1 \mu \mathrm{g} / \mathrm{ml}, 37^{\circ} \mathrm{C}\right.$, for 15 minutes), successively. After the slides were post fixed with $4 \%$ paraformaldehyde in PBS, the slides were immersed twice with 2 $\mathrm{mg} / \mathrm{ml}$ glycine in PBS for 15 minutes. Hybridization was carried out at $37^{\circ} \mathrm{C}$ for KGF and $42^{\circ} \mathrm{C}$ for KGFR overnight in a medium containing $10 \mathrm{~mm}$ Tris- $\mathrm{HCl}(\mathrm{pH}$
7.4), $1 \mathrm{~mm}$ EDTA, 0.6 M NaCl, $1 \times$ Denhardt's solution, $250 \mu \mathrm{g} / \mathrm{ml}$ yeast transfer RNA, $125 \mu \mathrm{g} / \mathrm{ml}$ salmon testis DNA, 10\% dextran sulfate, $200 \mathrm{U} / \mathrm{ml}$ heparin, 10 $\mu \mathrm{g} / \mathrm{ml}$ poly A, $40 \%$ deionized formamide, and 1.0 $\mu \mathrm{g} / \mathrm{ml}$ T-T dimerized KGF probe or T-T dimerized KGFR probe. After hybridization, the slides were washed 3 times with $2 \times \mathrm{SSC} / 50 \%$ formamide at $37^{\circ} \mathrm{C}$, twice with $0.5 \times \mathrm{SSC}$ in $50 \%$ formamide at $37^{\circ} \mathrm{C}$ for 1 hour each, and finally washed twice with $2 \times S S C$ at RT for 15 minutes. After successive treatment with ethanol and acetone to dilapidate the sections, the slides were subjected to enzyme-immunohistochemistry. After being immersed in blocking solution (5\% BSA, 100 $\mu \mathrm{g} / \mathrm{ml}$ salmon testis DNA, $100 \mu \mathrm{g} / \mathrm{ml}$ yeast transfer RNA, and $500 \mu \mathrm{g} / \mathrm{ml}$ mouse lgG in PBS) for 1 hour at $\mathrm{RT}$, the slides were reacted overnight with HRPmouse anti-T-T antibody (1:80) at RT. After washing with $0.075 \%$ Brij 35 in PBS, the visualization of $\mathrm{HRP}$ sites was performed with $\mathrm{DAB}, \mathrm{Ni}, \mathrm{Co}$, and $\mathrm{H}_{2} \mathrm{O}_{2}$ according to the method of Adams (1981). The proportion of cells positive for KGF mRNA was determined by an image analyzer (DAB system; Carl Zeiss, Thornwood, New York). Positive cells were evaluated based on the staining density over the level of staining with the sense probe using an image analyzer.

To confirm the specificity of mRNA signals, a variety of control experiments were conducted. In every experiment, sense probe was used as a negative control. To evaluate the level of hybridizable RNAs in tissue sections, a serial section used for 28S rRNA probes was used as a positive control in every case (Yoshii et al, 1995). Furthermore, some sections were hybridized with antisense probe in the presence of an excess amount of unlabeled antisense, unlabeled sense, or random oligo-DNA to provide definitive evidence for the sequence specificity of the signal as described previously in detail (Koji and Brenner, 1993).

\section{Identification of Proliferating Cells}

The nuclear antigen associated with cell proliferation was immunohistochemically detected using anti-Ki-67 antibody. For this purpose, sections were first deparaffinized, then the slides were autoclaved in $10 \mathrm{~mm}$ citrate buffer $\left(\mathrm{pH} \mathrm{6.0)}\right.$ for 15 minutes at $120^{\circ} \mathrm{C}$, according to the protocol described by Ehara et al (1995), and processed in a manner similar to that described above, except for the concentration of anti-Ki-67 antibody (1:100) and the use of HRP-goat anti-mouse $\lg G(1: 100)$ as a second antibody. As a negative control, some sections were incubated with normal mouse IgG instead of anti-Ki-67 antibody.

\section{Identification of Cell Type of KGF-Positive Cells in Cholesteatoma Tissue}

To identify the type of KGF-positive cells, we performed double-staining for KGF and various surface markers in the sections of cholesteatoma tissues. The section was reacted with anti-KGF antibody and surface markers such as anti-vimentin antibody, antipan-cytokeratin (5/6/8/18) antibody, anti-CD45R0 an- 
tibody, anti-CD 20cy antibody, or anti-S100 antibody. After deparaffinization, the slides were stained with anti-KGF antibody according to the protocol described above, and HRP sites were visualized with DAB and $\mathrm{H}_{2} \mathrm{O}_{2}$. Then the slides were immersed with PBS and autoclaved in $10 \mathrm{~mm}$ citrate buffer (pH 6.0) for 15 minutes at $120^{\circ} \mathrm{C}$ to detect vimentin and treated with $1.0 \%$ trypsin 250 and $1.0 \%$ calcium chloride in 50 $\mathrm{mm}$ Tris-buffered saline $(\mathrm{pH} 7.8)$ to detect pancytokeratin. Anti-CD45R0, anti-CD20cy, and antiS100 antibodies were stained without any pretreatment. Then, sections were immersed 3 times with 0.1 $\mathrm{M}$ glycine- $\mathrm{HCl}$ buffer ( $\mathrm{pH}$ 2.2) for 30 minutes. After washing with Milli-Q water once and being immersed with PBS three times, sections were stained by the same indirect immunohistochemistry described above. Sections were visualized with $4-\mathrm{Cl}$ naphthol and $\mathrm{H}_{2} \mathrm{O}_{2}$ solution. The optimal concentrations of the first antibodies are listed in Table 1. HRP-goat antimouse IgG (1:100) or HRP-goat anti-rabbit IgG (1:100) was used as the second antibody.

\section{Quantitative Analysis}

For quantitative analysis, more than 1000 cells were counted in random fields at $\times 400$ magnification, and the number of Ki-67-positive cells was expressed as a percentage of positive cells per total number of counted cells (Ki-67 LI; mean $\pm \mathrm{SD}$ ). The staining intensities of KGF and KGFR were graded as $(+)$ positive or (-) negative, compared with the background staining with normal rabbit lgG.

\section{Statistical Analysis}

All data for Ki-67 LI in normal skin and cholesteatoma tissues including KGF-positive, KGF-negative, KGFRpositive, KGFR-negative, both KGF and KGFR positive, recurrence-positive, and recurrence-negative cases were expressed as mean \pm SD. Differences in $\mathrm{Ki}-67 \mathrm{LI}$ between normal and cholesteatoma tissues, KGF-positive and KGF-negative cases, KGFRpositive and KGFR-negative cases, KGF and KGFR dual positive, and all other cases such as KGF-positive/KGFR-negative, KGF-negative/KGFRpositive and KGF-negative/KGFR-negative, and recurrence-positive, and recurrence-negative cases were examined for statistical significance using the unpaired Student's $t$ test. A $p$ value less than 0.05 denoted the presence of a statistically significant difference. All analyses were performed with a statistical software package (StatView, version 4.51; Abacus Concepts, Berkeley, California).

\section{References}

Adams JC (1981). Heavy metal intensification of DAB-based HRP reaction product. J Histochem Cytochem 29:775.

Alarid ET, Rubin JS, Young P, Chedid M, Ron D, Aaronson SA, and Cunha GR (1994). Keratinocyte growth factor functions in epithelial induction during seminal vesicle development. Proc Natl Acad Sci U S A 91:1074-1078.
Andreadis ST, Hamoen KE, Yarmush ML, and Morgan JR (2001). Keratinocyte growth factor induces hyperproliferation and delays differentiations in a skin equivalent model system. FASEB J 15:898-906.

Bagger-Sjoback D and Phelps PD (1985). Cholesteatoma with extension to the cochlea. Am J Otol 6:338-343.

Bajaj-Elliott M, Breese E, Poulsom R, Fairclough PD, and MacDonald TT (1997). Keratinocyte growth factor in inflammatory bowel disease. Increased mRNA transcripts in ulcerative colitis compared with Crohn's disease in biopsies and isolated mucosal myofibroblasts. Am J Pathol 151:14691476.

Barazzone C, Donati YR, Rochat AF, Vesin C, Kan CD, Pache JC, and Piguet PF (1999). Keratinocyte growth factor protects alveolar epithelium and endothelium from oxygeninduced injury in mice. Am J Pathol 154:1479-1487.

Boismenu R and Havran WL (1994). Modulation of epithelial cell growth by intraepithelial $\gamma \delta$ T cells. Science 266:12531255 .

Brauchle M, Angermeyer K, Hubner G, and Werner S (1994). Large induction of keratinocyte growth factor expression by serum growth factors and pro-inflammatory cytokines in cultured fibroblasts. Oncogene 9:3199-3204.

Brauchle M, Madlener M, Wagner AD, Angermeyer K, Lauer U, Hofschneider PH, Gregor M, and Werner S (1996). Keratinocyte growth factor is highly overexpressed in inflammatory bowel disease. Am J Pathol 149:521-529.

Brunner T, Arnold D, Wasem C, Herren S, and Frutschi C (2001). Regulation of cell death and survival in intestinal intraepithelial lymphocytes. Cell Death Differ 8:706-714.

Bujia J, Kim C, Ostos P, Kastenbauer E, and Hultner L (1996). Role of interleukin 6 in epithelial hyperproliferation and bone resorption in middle ear cholesteatomas. Eur Arch Otorhinolaryngol 253:152-157.

Cancilla B and Risbridger GP (1998). Differential localization of fibroblast growth factor receptor-1, $-2,-3$, and -4 in fetal, immature, and adult rat testes. Biol Reprod 58:1138-1145.

Cartun RW, Coles FB, and Pastuszak WT (1987). Utilization of monoclonal antibody L26 in the identification and confirmation of B-cell lymphomas. A sensitive and specific marker applicable to formalin-and B5-fixed, paraffin-embedded tissues. Am J Pathol 129:415-421.

Chedid M, Rubin JS, Csaky KG, and Aaronson SA (1994). Regulation of keratinocyte growth factor gene expression by interleukin 1. J Biol Chem 269:10753-10757.

Chole RA (1992). Cholesteatoma: conference summary. In: Nakano Y, editor. Cholesteatoma and Mastoid Surgery Fourth International Conference, Niigata, Japan, September 8-12, 1992. Amsterdam: Kugler Publishers, 835-840.

Choufani G, Mahillon V, Decaestecker C, Lequeux T, Danguy A, Salmon I, Gabius HJ, Hassid S, and Kiss R (1999). Determination of the levels of expression of sarcolectin and calcyclin and of the percentages of apoptotic but not proliferating cells to enable distinction between recurrent and nonrecurrent cholesteatomas. Laryngoscope 109:18251831.

Cocchia D, Michetti F, and Donato R (1981). Immunochemical and immuno-cytochemical localization of S-100 antigen in normal human skin. Nature 294:85-87. 
Edelstein DR and Parisier SC (1989). Surgical techniques and recidivism in cholesteatoma. Otolaryngol Clin North Am 22:1029-1040.

Ehara H, Koji T, Deguchi T, Yoshii A, Nakano M, Nakane PK, and Kawada $Y$ (1995). Expression of estrogen receptor in diseased human prostate assessed by non-radioactive in situ hybridization and immunohistochemistry. Prostate 27:304313.

Fehrenbach $\mathrm{H}$, Kasper M, Koslowski R, Pan T, Schuh D, Muller M, and Mason RJ (2000). Alveolar epithelial type II cell apoptosis in vivo during resolution of keratinocyte growth factor-induced hyperplasia in the rat. Histochem Cell Biol 114:49-61.

Finch PW and Cheng AL (1999). Analysis of the cellular basis of keratinocyte growth factor overexpression in inflammatory bowel disease. Gut 45:848-855.

Finch PW, Cunha GR, Rubin JS, Wong J, and Ron D (1995a). Pattern of keratinocyte growth factor and keratinocyte growth factor receptor expression during mouse fetal development suggests a role in mediating morphogenetic mesenchymal-epithelial interactions. Dev Dyn 203:223-240.

Finch PW, Lengel C, and Chedid M (1995b). Cloning and characterization of the promoter region of the human keratinocyte growth factor gene. J Biol Chem 270:11230-11237.

Finch PW, Murphy F, Cardinale I, and Krueger JG (1997). Altered expression of keratinocyte growth factor and its receptor in psoriasis. Am J Pathol 151:1619-1628.

Finch PW, Rubin JS, Miki T, Ron D, and Aaronson SA (1989). Human KGF is FGF-related with properties of a paracrine effector of epithelial cell growth. Science 245:752-755.

Fujioka O and Huang CC (1994). Platelet-derived growth factor in middle ear cholesteatoma. Eur Arch Otorhinolaryngol 251:199-204.

Fukuda $\mathrm{Y}$, Ito $\mathrm{Y}$, Azumi H, Edi NAS, Li ZL, Marumo M, Kasagawa O, and Otsuki $Y$ (2002). Cell death and proliferation in Nd-YAG laser, electrocautery, and scalpel wounds on mice skin. J Derm Sci 28:106-118.

Gatter KC, Abdulaziz Z, Beverley P, Corvalan JR, Ford C, Lane EB, Mota M, Nash JR, Pulford K, Stein H, TaylorPapadimitriou J, Woodhouse C, and Mason DY (1982). Use of monoclonal antibodies for the histopathological diagnosis of human malignancy. J Clin Pathol 35:1253-1267.

Giri D and Ittmann M (2000). Interleukin-1alpha is a paracrine inducer of FGF7, a key epithelial growth factor in benign prostatic hyperplasia. Am J Pathol 157:249-255.

Halaban R, Funasaka Y, Lee P, Rubin J, Ron D, and Birnbaum D (1991). Fibroblast growth factor in normal and malignant melanocytes. Ann NY Acad Sci 638:232-243.

Harker LA (1977). Cholesteatoma an evidence study. In: McCabe BF, Sade J, and Abramson M, editors. Cholesteatoma First International Conference. Birmingham: Aesculapius Publishers, 308-309.

Housley RM, Morris CF, Boyle W, Ring B, Biltz R, Tarpley JE, Aukerman SL, Devine PL, Whitehead RH, and Pierce GF (1994). Keratinocyte growth factor induces proliferation of hepatocytes and epithelial cells throughout the rat gastrointestinal tract. J Clin Invest 94:1764-1777.

Ishibashi T, Shinogami M, Kaga K, and Fukaya T (1997). Keratinocyte growth factor and receptor mRNA expression in cholesteatoma of the middle ear. Acta Otolaryngol 117:714718.

Jameson J, Ugarte K, Chen N, Yachi P, Fuchs E, Boismenu $\mathrm{R}$, and Havran WL (2002). A role for skin $\gamma \delta \mathrm{T}$ cells in wound repair. Science 296:747-749.

Johnson DE, Lu J, Chen H, Werner S, and Williams LT (1991). The human fibroblast growth factor receptor genes: A common structural arrangement underlies the mechanisms for generating receptor forms that differ in their third immunoglobulin domain. Mol Cell Biol 11:4627-4634.

Kim HJ, Tinling SP, and Chole RA (2001). Expression patterns of cytokeratins in retraction pocket cholesteatomas. Laryngoscope 111:1032-1036.

Kim HJ, Tinling SP, and Chole RA (2002). Expression patterns of cytokeratins in cholesteatomas: Evidence of increased migration and proliferation. J Korean Med Sci 17: 381-388.

Koji T and Brenner RM (1993). Localization of estrogen receptor messenger ribonucleic acid in rhesus monkey uterus by nonradioactive in situ hybridization with digoxigenin-labeled oligodeoxynucleotides. Endocrinology 132:382-392.

Koji T, Chedid M, Rubin JS, Salyden OD, Csaky KG, Aaronson SA, and Brenner RM (1994a). Progesterone-dependent expression of keratinocyte growth factor mRNA in stromal cells of the primate endometrium: Keratinocyte growth factor as a progestomedin. J Cell Biol 125:393-401.

Koji T, Kobayashi N, Nakanishi Y, Yoshii A, Hashimoto S, Shibata Y, Anjiki N, Yamamoto R, Ueda T, Kanazawa S, and Nakane PK (1994b). Immunohistochemical localization of Fas antigen in paraffin sections with rabbit antibodies against human synthetic Fas peptides. Acta Histochem Cytochem $27: 459-463$

Koji T and Nakane PK (1996). Recent advances in molecular histochemical techniques: In situ hybridization and southwestern histochemistry. J Electron Microsc 45:119-127.

Kojima $\mathrm{H}$, Matsuhisa K, Shiwa M, Kamide Y, Nakamura M, Ohno T, and Moriyama H (1996). Expression of messenger RNA for keratinocyte growth factor in human cholesteatoma. Arch Otolaryngol Head Neck Surg 122:157-160.

Kojima H, Shiwa M, Kamide $Y$, and Moriyama H (1994). Expression and localization of mRNA for epidermal growth factor and epidermal growth factor receptor in human cholesteatoma. Acta Otolaryngol 114:423-429.

Laemmli UK (1970). Cleavage of structural proteins during the assembly of the hand of bacteriophage T4. Nature 227:680-685.

Lang S, Schilling V, Wollenberg B, Mack B, and Nerlich A (1997). Localization of transforming growth factor-betaexpressing cells and comparison with major extracellular components in aural cholesteatoma. Ann Otol Rhinol Laryngol 106:669-673.

LaRochelle WJ, Dirsch OR, Finch PW, Cheon HG, May M, Marchese C, Pierce JH, and Aaronson SA (1995). Specific receptor detection by a functional keratinocyte growth factor-immunoglobulin chimera. J Cell Biol 129:357-366.

Marchese C, Rubin JS, Ron D, Faggioni A, Torrisi MR, Messina A, Frati L, and Aaronson SA (1990). Human keratinocyte growth factor activity on proliferation and differentiation of human keratinocytes: Differentiation response distinguishes KGF from EGF family. J Cell Physiol 144:326-332. 
Mason DY, Comans-Bitter WM, Cordell JL, Verhoeven MA, and van Dongen JJ (1990). Antibody L26 recognizes an intracellular epitope on the B-cell-associated CD20 antigen. Am J Pathol 136:1215-1222.

Mason IJ, Fuller-Pace F, Smith R, and Dickson C (1994). FGF-7 (keratinocyte growth factor) expression during mouse development suggests roles in myogenesis, forebrain regionalization and epithelial-mesenchymal interaction. Mech Dev 45:15-30.

Miki T, Bottaro DP, Fleming TP, Smith CL, Burgess WH, Chan AML, and Aaronson SA (1992). Determination of ligandbinding specificity by alternative splicing: Two distinct growth factor receptors encoded by a single gene. Proc Natl Acad Sci U S A 89:246-250.

Miki T, Fleming TP, Bottaro DP, Rubin JS, Ron D, and Aaronson SA (1991). Expression cDNA cloning of the KGF receptor by creation of a transforming autocrine loop. Science 251:72-75.

Moll R, Franke WW, Schiller DL, Geiger B, and Krepler R (1982). The catalog of human cytokeratins: Patterns of expression in normal epithelia, tumors and cultured cells. Cell 31:11-24.

Nakajima T, Watanabe S, Sato Y, Shimosato Y, Motoi M, and Lennert K (1982). S-100 protein in Langerhans cells, interdigitating reticulum cells and histiocytosis X cells. Gann 73:429432.

Norton AJ, Ramsay AD, Smith SH, Beverley PC, and Isaacson PG (1986). Monoclonal antibody (UCHL1) that recognises normal and neoplastic $T$ cells in routinely fixed tissues. J Clin Pathol 39:399-405.

Orr-Urtreger A, Bedford MT, Burakova T, Arman E, Zimmer Y, Yayon A, Givol D, and Lonai P (1993). Developmental localization of the splicing alternatives of fibroblast growth factor receptor-2 (FGFR-2). Dev Biol 158:475-486.

Osborn M, Debus E, and Weber K (1984). Monoclonal antibodies specific for vimentin. Eur J Cell Biol 34:137-143.

Planz B, Aretz HT, Wang Q, Tabatabaei S, Kirley SD, Lin CW, and McDougal WS (1999). Immunolocalization of the keratinocyte growth factor in benign and neoplastic human prostate and its relation to androgen receptor. Prostate 41:233-242.

Rubin JS, Osada H, Finch PW, Taylor WG, Rudikoff S, and Aaronson SA (1989). Purification and characterization of a newly identified growth factor specific for epithelial cells. Proc Natl Acad Sci USA 86:802-806.

Schilling V, Bujia J, Negri B, Schulz P, and Kastenbauer E (1991). Immunologically activated cells in aural cholesteatoma. Am J Otolaryngol 12:249-253.

Schilling V, Negri B, Bujia J, Schulz P, and Kastenbauer E (1992). Possible role of interleukin 1 alpha and interleukin 1 beta in the pathogenesis of cholesteatoma of the middle ear. Am J Otol 13:350-355.

Schulz P, Bujia J, Holly A, Schilling V, and Kastenbauer E (1993). Possible autocrine growth stimulation of cholesteatoma epithelium by transforming growth factor alpha. Am J Otol 14:82-87.

Sculerati N and Bluestone CD (1989). Pathogenesis of cholesteatoma. Otolaryngol Clin North Am 22:859-868.
Smith SH, Brown MH, Rowe D, Callard RE, and Beverley PC (1986). Functional subsets of human helper-inducer cells defined by a new monoclonal antibody, UCHL1. Immunology 58:63-70.

Smola H, Thiekotter G, and Fusenig NE (1993). Mutual induction of growth factor gene expression by epidermaldermal cell interaction. J Cell Biol 122:417-429.

Staiano-Coico L, Krueger JG, Rubin JS, D'limi S, Vallat VP, Valentino L, Fahey T, Hawes A, Kingston G, Madden MR, Mathwich M, Gottlieb AB, and Aaronson SA (1993). Human keratinocyte growth factor effects in a porcine model of wound healing. J Exp Med 178:865-878.

Sudhoff H, Bujia J, Fisseler-Eckhoff A, Holly A, Schulz-Flake C, and Hildmann H (1995). Expression of a cell-cycleassociated nuclear antigen (MIB 1) in cholesteatoma and auditory meatal skin. Laryngoscope 105:1227-1231.

Takasaka T, Houzawa K, Adachi M, Kawase T, Shiga N, Suzuki N, and Kobayashi T (1996). Pathogenesis of attic retractions and attic cholesteatomas. In: Sanna $M$, editor. Cholesteatoma and Mastoid Surgery Fifth International Conference, Rome, Italy, September 2-6. 1996. Rome: Cic Edizioni International, 296-300.

Terry LA, Brown MH, and Beverley PC (1988). The monoclonal antibody, UCHL1, recognizes a 180,000 MW component of the human leucocyte-common antigen, CD45. Immunology 64:331-336.

Tos M (1988). Incidence, etiology and pathogenesis of cholesteatoma in children. Adv Otorhinolaryngol 40:110-117.

Uyemura K, Deans RJ, Band H, Ohmen J, Panchamoorthy G, Morita CT, Rea TH, and Modlin RL (1991). Evidence for clonal selection of gamma/delta $T$ cells in response to a human pathogen. J Exp Med 174:683-692.

Werner S, Peters KG, Longaker MT, Fuller-Pace F, Banda MJ, and Williams T (1992). Large induction of keratinocyte growth factor expression in the dermis during wound healing. Proc Natl Acad Sci U S A 89:6896-6900.

Werner S, Smola H, Liao X, Longaker MT, Krieg T, Hofschneider PH, and Williams LT (1994). The function of KGF in epithelial morphogenesis and reepithelization of wound. Science 266:819-822.

Wilson SE, Liang Q, and Kim WJ (1999). Lacrimal gland HGF, KGF and EGF mRNA levels increase after corneal epithelial wounding. Invest Ophthalmol Vis Sci 40:2185-2190.

Yan SD and Huang CC (1991). Tumor necrosis factor alpha in middle ear cholesteatoma and its effect on keratinocytes in vitro. Ann Otol Rhinol Laryngol 100:157-161.

Yi ES, Williams ST, Lee H, Malicki DM, Chin EM, Yin S, Tarpley J, and Ulich TR (1996). Keratinocyte growth factor ameliorates radiation- and bleomycin-induced lung injury and mortality. Am J Pathol 149:1963-1970.

Yoshii A, Koji T, Ohsawa N, and Nakane PK (1995). In situ hybridization of ribosomal RNAs is a reliable reference for hybridizable RNA in tissue sections. J Histochem Cytochem 43:321-328. 